\title{
Editorial
}

\section{Impact of Research Conducted by Dr Douglas Wilson on World Science}

\author{
R.B. Singh ${ }^{\S} *$
}

Halberg Hospital and Research Institute, Civil Lines, Moradabad-10(UP) 244001, India

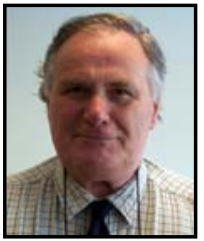

I personally and professionally know of Dr Douglas Wilson, who is a Member of the School of Medicine, Pharmacy and Health, Durham University, Stockton-on-Tees, UK, for more than a decade. His name was brought to my attention by my great Guru and Nobel Prize nominee Dr Franz Halberg and Dr Germaine Cornelissen who is a great scientist in her own right. While I was looking for a Statistical Consultant Referee for the World Heart Journal by Nova Science Publisher, NY, USA, I was very lucky to have him join our Editorial Board. I became closer to him because of his unassuming behavior, friendliness and readiness to help colleagues in conducting research, writing articles and sharing views on various original hypotheses. His views about prevention of diseases have a continuing influence on world research particularly related to chronobiology and clinical nutrition which prompts me to write this editorial.

Dr Wilson is employed as a statistician in the Research and Design Service (RDS), and is a Fellow of the Wolfson Research Institute for Health and Wellbeing. Douglas joined the team at the Department of School of Medicine and Health, Queen's Campus Durham University (based at the Wolfson Research Institute) in November 2008, to provide research design services to National Health Service (NHS) researchers in the North East of England. Dr Wilson's background was originally in industrial chemistry until his first professional opportunity which came when he joined Professor Keith Griffiths, Director of the Tenovus Institute for Cancer Research, whose own career was linked with some of the great early steroid endocrine pioneers of our time such as Professor Guy Frederic Marrian at Edinburgh University. Douglas developed an interest in medical statistics, endocrinology, breast and prostate cancer, radioimmunoassay, and helped to develop the Institute's programme in salivary steroid research of value to studies of cancer and nutrition. Dr Wilson's second major opportunity came when he met Professor Halberg, Father of Chronobiology, University of Minnesota, at the Institute in 1976, when a deep-rooted passion for temporal aspects of human development catapulted him into many research areas supported by the Cardiff and Minnesotan teams and Dr Wilson subsequently spent three

\footnotetext{
*Address correspondence to this author at the Halberg Hospital and Research Institute, Civil Lines, Moradabad-10(UP) 244001, India;

Emails: rbs@tsimtsoum.net,drkk@dataone.in

${ }^{\S}$ Guest Editor
}

decades as an international renown scientist presenting well over a hundred papers or so in over 30 countries in four out of 5 continents. These teams kept faith with Dr Wilson when due to funding problems, he joined the UK Governments Ministry of Agriculture Fisheries and Food (ADAS), his third opportunity, and later became Head of Statistics in ADAS where he developed a keen interest in food production and safety, microbiology, environment, horticulture, dairy, fruit, hops, animal husbandry and arable farming. He ran quite extensive training programmes in applied statistics, including experiment design, and was a contributor to what was probably hundreds of grant applications spanning 13 years.

Dr Wilson's expertise and experience dovetailed into my own activities and aspirations in nutraceuticals and the work of the Tsim Tsoum Institute, in Krakow. However, such links were facilitated by the extremely valuable support given to him by his Dean of Medicine, Professor A.P.S. Hungin that enabled him to present widely at Institutions around the world which collectively, in this paragraph, I believe, is his fifth professional opportunity in his 50 years as a practicing scientist, namely work on Nutrition and Functional Foods.

His principal outside interest has been the dissemination of science to the lay public, has given media interviews worldwide and he felt it pleasing to support my work in India on cardiovascular disease, particularly in support of Professor Halberg's work on blood pressure on Voice of America, albeit in a small but important way, and for many years he held High Offices, including President, in the prestigious Cardiff Scientific Society. Professionally, with Professor Griffiths, newsletters for the general public were produced and distributed on important cancer-related topics so that the public could have a balanced perception on issues such as diet and cancer. Members of the public were shown around the Institute nightly two of three times a week showing how their money was being spent and this did not include attending fund-raising events. The public were often at the forefront of the Institute's thinking on accountability, as is mine when it comes to policy and scientific issues and the health of mankind.

Dr Wilson has degrees in Chemistry and Biochemistry, Psychology, Biology, Reading Classics and Religious Studies, and has read many other subjects at University level including French, Physics, Economics, Economic History 
Mathematics and Statistics, Geology and Cosmology, quite apart from Doctorates with topics on Cancer, Chronobiology, and Agricultural Science: these do not include preuniversity technical qualifications in Chemistry, Physics and Mathematics.

Of particular relevance to food and nutrition, is his work with the Department of Agriculture in Bucharest, Romania, where he contributed to the design and collection of data for crop produce from judeţes for EUROSTAT necessary for Romania's entry into the EU: his knowledge of the design and analysis of surveys in agriculture, and in science at the University of Limerick, are an asset to epidemiological studies which he and Professor Griffiths undertook in Thailand on female human development. He was also a Member of the Association of Applied Biologists at Horticulture International, UK. He was invited to the Royal Society of Edinburgh to talk on phytoestrogens and cancer risk and was an invited 'training presenter' to Italian Doctors and Researchers at the Ettore Majorana Centre for Scientific Culture, Erice, Sicily.

Chronobiology is a fundamental discipline in life science. Dr Wilson was on the International Board of the International Society for Chronobiology; Inaugural Chairman of the British Society and Member of the European Society of Chronobiology. Chronobiology and the environment are inextricably linked. He was Vice President of the International Society for Civilization Diseases and the Environment, and Member of the Association for the Social Study of Time (ASSET) headed by the late Lord Michael Young of Dartington.

From a statistical perspective, so important as a reviewer of submissions to journals and in research work, he was Vice Chairman of the Institute of Statisticians, external Examiner in applied statistics for the University of Central Lancashire; Assessor of courses in statistics; with colleagues he conducted many training courses in agricultural statistics and external quality control programmes for laboratories within the NHS. Although not a member, he was an invited speaker to PSI (Statistician's in the Pharmaceutical Industry). He was a company director and also supervised postgraduate students. For many years Dr Wilson was statistical advisor on reference materials the European Community of Reference (BCR) for steroids and mass spectroscopy. With his col- leagues, he conducted many trials/studies in prostate and breast cancer. He was one of the Founder Members of the British Prostate Study Group in the 1970s.

Dr Wilson is a past and current reviewer of many journals of which those given below are but just a global snapshot and include:- Geophysical Processes and the Biosphere; Journal of Clinical Endocrinology and Metabolism; Journal of Applied Biomedicine; Journal of Inflammation; World Heart Journal; American Medical Journal; Journal of USChina Medical; and Online Journal Biological Sciences, etc.

Dr Wilson has tremendous interest in the study of environment as a chronobiologist but he shares the same views about nutrition and lifestyle factors as we have in the Tsim Tsoum Institute, namely 'health for all' through prudent diet. Indicators of esteem include the Jules Verne Medal in 1990 from the City of Nantes for work on Cancer Research; Certified Fellow Specialist of Clinical Hypertension (19th February 2010) conferred by Indian Society for Hypertension (FSCH). Fellowship and Membership of Professional Bodies include Chartered statistician; Fellow: Royal Statistical Society; Chartered mathematician; Fellow Inst. Math and Appl.; Chartered Engineer; Member Brit Comp. Soc. (Chairman of the Branch in South Wales); Senior Member of The Endocrine Society; Chartered Biologist and Fellow of the Society of Biology (Formerly honorary President of South Wales Branch; Chartered IT Professional; Chartered Scientist, Life Member of the Indian Society for Hypertension; Member (Formerly President) International Society for Clinical Biostatistics; Fellow of the Tsim Tsoum Institute; Member of 'The International Society for Clinical Biostatistics; Fellowship of the International College of Nutrition (FICN) (Canada).

\section{Publications}

With close to 350 papers and presentations, Dr Wilson has joined The Tsim Tsoum Institute, Krakow, Poland along with Fabien De Meester and Agnieszka Wilkzynska and myself, Ram B Singh, whose goal is to intervene and prevent global diseases through nutritional means and in so doing improve the social, mental, and spiritual well being of mankind: which in part is the objective of this journal. That is our common aim and all those who join us: Dr Wilson is but one amongst many who shares these views.

\section{Prof. Dr. R.B. Singh, $M D$}

Halberg Hospital and Research Institute,

Civil Lines, Moradabad-10(UP) 244001, India

Emails: rbs@tsimtsoum.net, drkk@dataone.in

\section{(C) R.B. Singh; Licensee Bentham Open.}

This is an open access article licensed under the terms of the Creative Commons Attribution Non-Commercial License (http://creativecommons.org/licenses/ by-nc/3.0/) which permits unrestricted, non-commercial use, distribution and reproduction in any medium, provided the work is properly cited. 